\title{
"Writing to Learn or Learning to Write". A Critical Review of "English as a Foreign Language" (EFL) Teaching Practices in Writing in Saudi Universities
}

\author{
"Escribir para aprender o Aprender a escribir'": una revisión crítica de las prácticas de \\ enseñanza English as a Foreign Language (EFL) en escritura en universidades sauídes \\ "Escriure per a aprendre o Aprendre a escriure": una revisió crítica de les pràctiques \\ d'ensenyament "English as a Foreign Language (EFL)" en escriptura en universitats \\ saudites
}

Sahal Alshammari*

Department of Language \& Translation, Northern Border University, Arar, Saudi Arabia

*Corresponding author: alshammarisahal@gmail.com (Sahal Alshammari)

Received: 09/09/2019 | Accepted: 02/03/2020 | Published: 06/24/2020

\begin{abstract}
Developing proficiency in English writing has always been a challenge for L2 learners in general and Saudi learners in particular. Despite the widespread presence of English departments as a result of the sharp rise of Saudi universities in the previous decade, the numbers of outcomes or achievements in terms of skills are very discouraging. This paper aims to study this issue closely by investigating the most crucial elements that are likely to explain this weakness by reviewing the related empirical and theoretical studies in the Saudi context. This paper also aims to present to researchers a quick reference as to how English writing skills have evolved in Saudi Arabia in the recent past, and specifies the challenges faced not only by Saudi L2 learners but also professionals involved in English language teaching. Moreover, this paper provides the professional with an overview of all the pedagogical improvisations carried out so far in the Saudi teaching context and suggests a path for moving forward.
\end{abstract}

Citation: Alshammari, S. (2020). "Writing to Learn or Learning to Write". A Critical Review of "English as a Foreign Language" (EFL) Teaching Practices in Writing in Saudi Universities. Research in Education and Learning Innovation Archives, 24,1-22. 10.7203/realia.24.15867

Copyright: The Authors. Open Access: This article is distributed under the terms of the Creative Commons Attribution-NoDerivatives 4.0 International licence (CC BY-ND 4.0)

Funding: None informed
KEYWORDS: writing; EFL; Saudi learners; teaching practices; L2

RESUMEN: Desarrollar el dominio de la escritura en inglés siempre ha sido un desafío para el alumnado de nivel 2 en general y para el alumnado saudí en particular. A pesar de la presencia generalizada de departamentos de inglés en universidades saudíes desde la década pasada, los resultados y logros son desalentadores. Este artículo investiga de cerca esta situación, tratando de encontrar los aspectos que pueden explicar esta debilidad. Para ello se revisan los más importantes estudios empíricos y teóricos relacionados con el contexto saudí. Este trabajo presenta una panorámica general sobre cómo las habilidades de escritura en inglés han evolucionado en Arabia Saudita en el pasado reciente, y detalla los desafíos que enfrentan no solo el alumnado saudita de nivel 2 sino también los profesionales involucrados en la enseñanza del idioma inglés en este país. Además, se ofrece una visión de las principales innovaciones pedagógicas llevadas a cabo en este terreno y se sugiere un camino de desarrollo futuro.

PALABRAS CLAVE: escritura; Inglés como lengua extranjera; alumnado saudí; prácticas de aprendizaje; L2 
RESUM: Desenvolupar el domini de l'escriptura en anglès sempre ha sigut un desafiament per als estudiants de nivell 2 en general i per a l'alumnat en particular. Malgrat la presència generalitzada de departaments d'anglès en universitats saudites des de la dècada passada, els resultats i assoliments són descoratjadors. Aquest article investiga de prop aquesta situació, i tracta de trobar els aspectes que poden explicar aquesta feblesa. Per això es revisen els més importants estudis empírics i teòrics relacionats amb el context saudita. Aquest treball presenta una panoràmica general sobre com les habilitats d'escriptura en anglès han evolucionat a Aràbia Saudita en el passat recent, i detalla els desafiaments que afronten no sols l'alumnat saudita de nivell 2 sinó també els professionals involucrats en l'ensenyament de l'idioma anglès en aquest país. A més, s'ofereix una visió de les principals innovacions pedagògiques dutes a terme en aquest terreny i se suggereix un camí de desenvolupament futur.

PARAULES CLAU: escriptura; alumnat saudí; práctiques d'aprenentatge; L2; anglès com a llengua estrangera

\section{Practitioner Notes}

\section{What is already known about the topic}

- Teaching practices in the area of ESL/EFL have been greatly evolved over the years. Various researches have touched upon the factors related to ESL/EFL teaching, but the results have failed to generate similar outcomes in different contexts. Saudi Arabia has implemented many reforms in educational sector, but the lack of desired English language skills, especially writing, among the undergraduate students is still a way below the global standards. Existing research has explored the popular existing practices critically, and has proposed the way forward.

\section{What this paper adds}

- Researches have investigated the factors related to ESL/EFL teaching and learning practices in isolation, such as teachers' and learners' perceptions, motivation, teachers' and learners' aptitude, L1 influence on ESL learning, cultural and social influence etc., but the existing research critically examines all the studies published in the context of Saudi Arabia, related to teaching writing, with reference to global perspective of ESL/EFL education. This paper reflects on all the factors related to ESL teaching and learning writing practices in the context of Arabic as L1 context in general and Saudi Arabia in particular. Moreover, it provides a quick reference to various stakeholders involved in English education in the kingdom.

\section{Implications of this research and/ or practice}

- While undergraduate students in Saudi universities are expected to have desired English language skills in order to further advance in their specialized areas of study, writing skill has proved to be the most challenging experience for the students as well as the teachers. The other factors like, teaching methodology, strategies and other cultural and social factors which directly and indirectly impacts the expected outcomes. There is a need to have a comprehensive view of the prevalent practices so as to identify each of the related factors in detail, to gain a better understanding of how writing is taught and what are the factors which influence their active learning.

\section{INTRODUCTION}

It is believed that teaching English in Saudi Arabia began in 1928 (Al-Seghayer, 2014) and was formally introduced in schools in 1937 (Barnawi \& Al-Hawsawi, 2017). Since then, it has expanded significantly. Namely, in 1971, English became a mandatory subject in public and private schools at both intermediate and secondary level (Mahboob \& Elyas, 2014), while in 2003 it was introduced as a regular subject in primary schools (Elyas, 2008). With regard to English departments within universities, the number of these departments has jumped from seven to thirty-one as a result of the 
rapid increase of universities in Saudi Arabia during 2006-2012 (Alshammari, 2016). In the early stages of education, English teachers in public schools came from neighboring countries such as Egypt, Syria, Sudan, and Jordan (Zaid, 1993). However, due to the widespread growth of universities in Saudi Arabia, most English teachers now-adays are Saudi nationals. Unfortunately, the graduates of English departments in Saudi universities who went on to teach English at public schools did not improve the quality of English language outcomes (Barnawi \& Al-Hawsawi, 2017). Education First English Proficiency Index (EF-EPI, hereafter) tested the level of students' English in public schools in Saudi Arabia over a six-year period (2007 -2012), concluding that Saudi learners in 2013 occupied the lowest ranking in terms of the English proficiency level index (Education First-English Proficiency Index (EF-EPI) , 2018). Table 1 suggests the status of the English language proficiency of Saudi Arabia over the last five years:

Table 1. EE EPI score distribution of Saudi Arabia from 2015 to 2019

\begin{tabular}{llllll}
\hline Year & $\begin{array}{l}\text { World } \\
\text { Ranking }\end{array}$ & $\begin{array}{l}\text { Average EE } \\
\text { EPI Score of } \\
\text { Saudi Arabia }\end{array}$ & $\begin{array}{l}\text { Average EE } \\
\text { EPI Score of } \\
\text { Middle East }\end{array}$ & $\begin{array}{l}\text { Position in } \\
\text { Middle East }\end{array}$ & Status \\
\hline 2019 & $98 / 100$ & 41.60 & 44.60 & $10 / 10$ & $\begin{array}{l}\text { Very Low } \\
\text { Proficiency }\end{array}$ \\
2018 & $83 / 100$ & 43.65 & 46.02 & $10 / 10$ & $\begin{array}{l}\text { Very Low } \\
\text { Proficiency }\end{array}$ \\
2017 & $72 / 80$ & 43.98 & 45.31 & $9 / 9$ & Very Low \\
2016 & $68 / 72$ & 40.91 & 43.62 & $11 / 13$ & $\begin{array}{l}\text { Proficiency } \\
\text { Very Low } \\
\text { Proficiency }\end{array}$ \\
& & & & $12 / 13$ & $\begin{array}{l}\text { Very Low } \\
\text { Proficiency }\end{array}$ \\
\hline
\end{tabular}

As it is shown in above table, the rank of Saudi remained at the bottom for the last five years regardless of the costly attempts to reform education over the past five years. Moreover, half of the population in Middle East is under 30, so providing jobs to everyone is impossible for public sector enterprises. Therefore, Gulf States have carried out major educational reforms and have allowed most of the public as well as private institutions to westernize their curricula to switch over to English in most of their degree programs (Education First-English Proficiency Index (EF-EPI), 2019). The change is slower though the literacy rates have risen sharply over the years. UAE and Iran have improved a lot in terms of higher language proficiency over the years. Surprisingly, in Saudi Arabia, the age groups 18 -20, 21-25, 26-30, 3140 speak English roughly at the same level (Education First-English Proficiency Index (EF-EPI), 2019). Not just English language learning is putting a serious question on the educational setting, the other areas of education also report a similar situation. Latest Program for International Student Assessment (Programme for International Student Assessment (PISA), 2015) testing reports that most of the Gulf States, especially Saudi Arabia, scored at the lowest available benchmarks for reading, math, and science. PISA and EF-EPI reports show the poor state of English language proficiency in Saudi Arabia which is way behind the expected results.

More specifically, many studies indicate an obvious weakness in the writing skills of Saudi learners (Alrabai, 2014a; Alshammari, 2016, 2018a, 2018b; C. Z. Javid \& Umer, 2014). Though these previous studies vary in terms of the methodological aspects of their research, i.e. either qualitative or quantitative studies, they agree on the conclusion that Saudi learners present serious problems with writing skills at both the micro and macro levels. 


\subsection{Purpose of the Study}

It is crucial to study the context in which L2 learners learn English language, in order to better understand their level of English language ability, particularly with English writing. This paper will discuss the elements that have essential and direct impact on writing, and will elaborate on the significance of each element, to comment on how such factors play out in the Saudi context in an attempt to shed light on the writing weaknesses of Saudi L2 learners who major in English at Saudi universities.

Since teaching of writing in EFL involves various factors such as the interference of L1, the strategies and techniques followed in learning context, the role of instructors and their feedback mechanism to get the maximum output, motivation level of the learners in improving their writing skill which is relatively demanding and requires a lot of time to achieve a desirable fluency. For easy reading, the paper has been divided into various sections. Section 1 starts with a brief introduction of the EFL writing practices in general, which is further connected to the theoretical foundations of writing theories that are relevant in the Saudi context in section 2. Section 3 and 4 focus on the role of L1 and teaching strategies followed in writing classes in Saudi universities. Section 5 and 6 assess the role of instructors and the feedback mechanism they follow in their writing classes. These sections also reflect on the students' concerns with regard to writing classes. Section 7 and 8 reflect on the motivation level of the students as well as teachers' perception on the same. The status of English writing among learners majoring in English language is also discussed at length.

\section{WRITING THEORIES IN GENERAL AND IN THE CONTEXT OF EFL PRACTICE IN SAUDI ARABIA}

Writing emerged as a distinct area of scholarship in the 1980s when various theoretical models were proposed to account for teaching of writing in ESL context. A theory is meaningless unless it is physically realized or tested (Camp, 2001; Strickland, 2001). Over the last two decades, the theories have been tested in various contexts. As second language education have evolved from the Grammar Translation Method (henceforth, GTM) to the Audio Lingual Method (henceforth, ALM) to the more communicative approaches that are commonly used today, ideas about how language proficiency develops and ought to be taught have also changed. Table 2 below illustrates the major approaches followed in L1, L2, and FL writing practices.

From Table 2, it is evident that FL has always been treated as SL, mainly in terms of pedagogical approaches. Even L2 is devoid of any comprehensive and coherent theory of L2 writing (Silva, 1993). Silva (1990) proposed four stages of writing instruction in ESL context which are governed by very influential theories in the field of English language teaching. Table 3 demonstrates these stages.

Until recently, the communicative approaches have found to focus more on oral proficiency than writing. But the idea of 'writing to learn' has generated a new interest in writing across the curriculum, writing for academic purposes, in composition, and also in English as second/foreign language learning. Ample research indicate that basic language literacy can be developed by those who are already literate in a first language, but the studies suggest that Saudi Arabia 's quality language learning in the first language impacts EFL as well. Until the nature of second/foreign writing is fully explored so as to assess how the students learn to write correctly, actual current practices in EFL classrooms will be slow to change.

The title of the paper suggests that the prevalent practices, with regard to writing in EFL instruction, are simply influenced by 'learning to write' approach, which is way behind 'writing to learn' strategies. In most of ESL settings, 'writing to learn' is seen a 
Table 2. Approaches for teaching writing in L1, L2, FL contexts

\begin{tabular}{|c|c|c|}
\hline \multicolumn{3}{|c|}{ Approaches in Writing Practices } \\
\hline L1 & L2 & $\mathrm{FL}$ \\
\hline The process approach & The controlled-to-free approach & $\begin{array}{l}\text { There is no well-defined approach } \\
\text { to teaching foreign language } \\
\text { writing per se. }\end{array}$ \\
\hline The prose model approach & The freewriting approach & $\begin{array}{l}\text { Audiolingual approach (dominant } \\
\text { in } 1950 \text { s and } 1960 \text { s) It focused } \\
\text { on oral language and treated } \\
\text { writing as support skill. }\end{array}$ \\
\hline The experiential approach & $\begin{array}{l}\text { The pattern-paragraph } \\
\text { approach }\end{array}$ & $\begin{array}{l}\text { Communicative approach } \\
\text { (1970s) Notion of communicative } \\
\text { competence applied both to } \\
\text { writing and speaking. }\end{array}$ \\
\hline The rhetorical approach & $\begin{array}{l}\text { The } \\
\text { grammar-syntax-organization } \\
\text { approach }\end{array}$ & $\begin{array}{l}\text { ACTFL Proficiency Guidelines } \\
\text { (1986). Emphasized on all the } \\
\text { four language skills (Listening, } \\
\text { Speaking, Reading and Writing) }\end{array}$ \\
\hline The epistemic approach & \multicolumn{2}{|l|}{ The communicative approach } \\
\hline A linguistic system approach & \multicolumn{2}{|l|}{ The process approach } \\
\hline
\end{tabular}

Table 3. ESL writing practices: theories, approaches (Silva, 1990)

\begin{tabular}{lll}
\multicolumn{1}{c}{ Theories } & \multicolumn{1}{c}{ Stages } & \multicolumn{1}{c}{ Dominant Ideas } \\
\hline $\begin{array}{l}\text { Communicative } \\
\text { Theory (Kennedy, 1998) }\end{array}$ & $\begin{array}{l}\text { Stage 1: Controlled } \\
\text { /guided approach }\end{array}$ & $\begin{array}{l}\text { Influenced by structural linguistics and behavioral } \\
\text { psychology, proposed learning as habit formation }\end{array}$ \\
$\begin{array}{l}\text { Contrastive rhetoric } \\
\text { Theory (Kaplan, 1966) }\end{array}$ & $\begin{array}{l}\text { Stage 2: } \\
\text { Current-traditional } \\
\text { rhetoric approach }\end{array}$ & $\begin{array}{l}\text { (1966) proposed internalizing the organizational } \\
\text { patterns }\end{array}$ \\
$\begin{array}{l}\text { Cognitive development } \\
\text { theory (Flower \& Hayes, }\end{array}$ & $\begin{array}{l}\text { Stage 3: Process } \\
\text { approach }\end{array}$ & $\begin{array}{l}\text { Effective and efficient writing development (from } \\
\text { pre to post stages of writing) }\end{array}$ \\
$\begin{array}{l}\text { Social } \\
\text { constructivist (Flower, }\end{array}$ & Stage 4: Social & Approximation with the discourse community \\
1994) & approach & \\
\hline
\end{tabular}

process wherein the learners are actively involved in varieties of contexts and domains of educational pursuit to engage in a discourse (Brookes \& Grundy, 1990), whereas 'learning to write' is more a structure-driven strategy, mostly found effective in EFL context, and not very encouraged in foreign language learning. However, in Saudi Arabia, this has been a dominant practice, focusing more on the linguistic structures than the overall development of the ideas.

Writing has long been considered a support skill for learning grammar in foreign language instruction (Homstad \& Thorson, 1994). It has always been used to reinforce the acquisition of grammar (as in GTM), or to support the memorization of language structures (as in ALM). Their research suggests that the theorists and practitioners in second/foreign language instructions are pushing the boundaries of standard language instruction practices by adopting new methods quite familiar to composition studies. Foreign language instructors favor 'process' approach to writing.

Writing theories related to L1 have developed into a number of different schools of thought: the expressive school of thought (Moffett, 1968), the cognitive school of thought (Britton, Burgess, Martin, McLeod, \& Rosen, 1975); the interactionists (Swales, 1990) and the constructivists (Halliday \& Martin, 1993). On the other hand, the main approaches that influence L2 writing are controlled, rhetorical, process, and English 
for Specific Purposes (Bacha, 2002). Controlled writing bases its roots on the audiolingual approach by which pattern practices and grammar accuracy are emphasized. This approach is preferred by teachers who tend to give specific orders and expect learners to follow them. In such classrooms, there is less freedom, and the environment is a controlled one, where the instructor is the center of every activity in the classroom. The audio-lingual approach is the dominant approach when it comes to teaching English in Saudi Arabia (Al-Seghayer, 2005). However, some of the audio-lingual elements, such as using language laboratories are missing in the Saudi context (Zaid, 1993), making the Audio-lingual method (ALM) similar to the Grammar Translation Method (GTM). Al-Seghayer (2005) noted that the GTM is used in the Saudi context along with ALM. Both methods focus on grammatical drills as an approach to improving writing, while the L1, Arabic, is widely used in the classroom. This methodology with regard to teaching English and particularly writing prepares learners who cannot express themselves orally and in writing.

There are several reasons behind the dominance of GTM and ALM in the Saudi classroom. First, although teachers and instructors came from different countries and cultural backgrounds, they are otherwise similar in that they share the same cultural principles. Further, their academic backgrounds are similar since there are no significant differences among Arab universities. Second, Saudi culture supports the teacher's dominance in the classroom since older adults are given the upper hand in every aspect of family life (Al-Zarah, 2008; Wiseman, 2010). For example, it is a custom in Saudi society that in a family setting, the oldest member, a father or elder brother, sits in the front where everybody can easily look at him. In this setting, the discussions go through him and nobody dares to neglect his presence. One can presume that, similarly, teachers in the classroom exercise their power, knowingly or unknowingly, not as per schools' policy, but as a cultural element that is prevalent in the social life. It is not unexpected that the classroom replicates the family setting, and that learners look up to their teachers as information givers. This gives an idea of the "banking" model of education, in which students are mere recipients of the teacher's wisdom (Alrabai, 2014a; Alrashidi \& Phan, 2015; Freire, 1970; Rajab, 2013).

Though the process approach appears to beneficial with regard to Saudi L2 learners' writing (Alshammari, 2016), the product approach is still a preferred strategy in teaching writing in English in the Saudi context (Ezza, 2010; Grami, 2010) as well as in Arabic (Bakry \& Alsamadani, 2015). In the product approach, the instructor focuses on the final paper a student writes, and does not involve in the cognitive operation that takes place prior to that production (Badger \& White, 2000). On the other hand, the process approach concentrates on the mental processes that take place in the writer's mind before producing the final paper. Unlike in the Saudi context, the process approach is considered as the dominant approach to teaching writing in the United States (Applebee \& Langer, 2009).

\section{THE ROLE OF THE L1}

The 1950s witnessed the birth of contrastive analysis (Lado, 1957), whereas Kaplan (1966) drew important insight regarding the negative transfer of L1 writing styles while acquiring L2 writing skills. Through his experience of teaching international students, he claimed that because of the distinctive contrasts between styles of writing with regard to English and with regard to other languages such as Arabic, L2 learners transfer their rhetorical strategies to the L2, and produce writing that does not meet the audience's expectations (Kaplan, 1966). He paved the way for a new approach at that time, contrastive analysis, and considered L1 to have a significant influence in terms of acquiring the L2. Many studies, consequently, have focused on the different aspect $\mathrm{s}$ of L1 and L2 in terms of how they can influence each other on the micro level. For 
example, Arab learners show difficulties when it comes to acquiring irregular English spelling systems such as the final /-e/ as in write, and the /-h/ in w-questions (Khan, 2011; Kharma \& Hajjahj, 1997; Mohammad \& Hazarika, 2016).

On the macro level, Ostler (1987) investigated how advanced Arab learners' written English differ from English native speaker's written English. Comparing the writing samples of 22 Saudi students to 10 English paragraphs selected from different books, she found that Arab learners write longer clauses than native English speakers. She attributed this to the coordination structure which is a preferred structure in Classical Arabic (Ostler, 1987).

However, though Kaplan's (1966) theory became a landmark in teaching and research in second language writing, and many researchers supported it (Al-Rubaye, 2015), some researchers questioned its concepts and tried to prove that the L1 language does not have a significant influence on learning to write. Gherwash (2015) claimed that, in fact, Arab learners generally do not have a developed knowledge of Arabic writing styles since learners use vernacular Arabic on a daily basis, and classical Arabic is used only in a limited context such as in schools or in official work. As a result, the claim that L1 language influences the learning of L2 writing is inaccurate. She investigated the impact of the differences between written and spoken Arabic on Arab L2 learners while acquiring writing skills. Moreover, her study focused on the impact of cultural, historical, sociopolitical, and institutional factors on how literacy is acquired, practiced, and valued in the Arab world (Gherwash, 2015).

The participants of the study represented five Arab countries: Algeria, Jordan, Kuwait, Saudi Arabia, and Yemen. She concluded that the colloquial variety of Arabic -not Classical Arabic- has a significant influence on Arab students' writing. Gherwash (2015) based her claim on the analysis of her participants' experience in that the majority indicated that the teaching of Arabic writing, unlike reading, was less systematic and there was an imbalance between the participants' proficiency in classical and colloquial Arabic. Conversely, while learning English writing, the participants reported well -established experiences with regard to producing good writers. In addition, a study by Ismail (2010) questioned Kaplan's theory about L1 negative transfer by comparing and analyzing the persuasive writing of 30 native Arabic and 30 native English learners. The results did not reveal any significant influence on the part of the participants' L1 language and cultural background. Surprisingly, the study could not find any significant difference in the rhetorical performance of advanced native Arabic speakers and native English speakers (Ismail, 2010). Moreover, researchers found out that L2 learners from different backgrounds show same errors in L2 and that some of these errors cannot be predicted by contrastive analysis theory (Schmitt, 2010). On the other hand, L1 language influence has an evident influence on L2 writing, particularly with prepositions (Bosede, Helen, \& Oluwakemi, 2015; Haddad, 2018).

Teaching writing to L2 learners who already have a complex and highly different writing system in their L1 will be difficult if we ignore the differences and the similarities between the two languages. Therefore, universal writing books will not be very useful for L2 learners because they, unlike L1, have already studied a writing system and will always use it as reference while they are learning L2 writing system.

\section{TEACHING STRATEGIES}

John Dewey 's (1938) and Freire's (1970) insights on teaching are based on sharing rather than depositing knowledge into a learner's mind. Freire (1970) criticized the absence of an engagement process of learning in the classroom, and described the traditional model of teaching as a "banking model", where teacher s squeeze the information into the learner's mind without any interaction from the learner's part (Freire, 
1970). Dewey went further and demanded that the educator begins with what students already know, so that the learning becomes more concrete rather than just based on abstract theoretical concepts (Bailey, n.d.). Since 1987 until 2000, many processes (e.g. hypothesizing, comparing, elaborating, modelling, questioning, repeating, monitoring, revising, organizing, planning, resourcing etc.) were identified which shape writing development. $\mathrm{Mu}$ (2005) classified all the processes into broad strategies (Rhetorical, Meta-cognitive, Cognitive, Communicative, and Social/Affective). These processes define the nature of various strategies, and how these processes are used in making the strategies effective and result oriented.

Unfortunately, the dominant approach in teaching writing in Saudi Arabia in a second language context bases its fundamentals on a teacher- centered approach (Whitefield \& Pollard, 1998, as cited in Grami, 2012). Unlike Dewey's and Freire's insights, English teacher s in Saudi Arabia are the dominant figures in the classrooms, and interaction between students goes only through him (Al-Seghayer, 2014). The dominant approach to teaching English in Saudi Arabia is GTM (Al-Seghayer, 2014). GTM focuses on grammar structures and emphasizes vocabulary memorization based on the translation of word meaning into the mother language. However, the focus on language grammar to teach the second language is no longer sufficient nor efficient, and learners should learn the language in such a way as to be able to communicate (communicative competence) rather than knowing its rules and structures (grammar competence) Bailey (n.d.). Since the audio-lingual and the translation approaches are the dominant approaches in teaching English in the Saudi context, learners can pass the exam and be considered good writers. Therefore, Saudi L2 depends on memorizing passages and reproducing them accurately in the test (Bakry \& Alsamadani, 2015; Mohammad \& Hazarika, 2016).

Other reasons attributed to Arab L2 weaknesses in writing are educational policies, the organization of teaching materials and resources, and different levels of language aptitude and diverse linguistic backgrounds (Ezza, 2010; Naheed, 2011). A recent qualitative study investigated the case of three students from three different Saudi universities (Alshammari, 2018b). The study focused on writing skills and how the participants had been taught writing while they were majoring in the English language in the undergraduate level. Though they were from different universities, and with a high aptitude for learning, the participants agreed that writing classes lack motivation, effective feedback, clear syllabi, and clear course objectives (Alshammari, 2018b). Other studies support these claims as well, arguing that writing skill can be time-consuming activity if not correlated with solid strategies (Knoch, Rouhshad, Oon, \& Storch, 2015; Knoch, Rouhshad, \& Storch, 2014). Investigating the influence of three years of study at an English medium university revealed no significant improvement in accuracy, grammatical complexity, and scores in global standardized tests, and the researchers attributed this failure to limited writing practice and teacher feedback (Knoch et al., 2015).

In addition, Arab learners have a major macro-linguistics failure when it comes to writing, due to different reasons such as unqualified teachers, inadequate teaching practice, and insufficient exposure to authentic texts in English (Fareh, 2014). Two major studies in particular, were conducted to investigate the influence of using language- learning strategies to improve the writing skills of Saudi EFL students. The first was conducted by Mcmullen (2009) who conducted her study on three sample universities in Saudi Arabia. The participants of the study were 71 male and 94 female students who were all enrolled in similar Freshman English composition courses. The results show that the participants benefited from various language learning strategies like social, meta-cognitive, and compensation (Mcmullen, 2009). For example, after training in a language learning strategy, the participants learned to compensate for words they do not know the spelling of with synonyms they we re familiar with, such 
as "pretty" instead of "beautiful". In general, the language learning strategy improved the students' writing organization, coherence, and mechanics (Mcmullen, 2009).

Along with the effectiveness of using strategies, the importance of using the language outside the classroom has proven to be the crucial factor in developing writing skills (Knoch et al., 2015). For example, the integration of an L2 learner with a native speaker of the target language has been found to be a significant factor in increasing the accuracy of writing for L2 language learners (Storch and Hill, 2008, as cited in Knoch, 2015). However, the participants noted that immersion in the L2 medium will not always improve writing skills if the writing program does not have enough practice and does not offer effective teacher feedback. To solve this problem, Aljumah (2012) investigated the influence of using a blog in support of Saudi L2 learners who are majoring in English. Thirty-five students participated in the study through a writing course where they use a blog designed by the researcher. Participants were asked to write an entry of 150 words per week, and to comment on at least two of their classmates' blogs. The significance of the study is that it was not limited to the classroom situation but was conducted as an out-of-class project. At the end of the semester, a questionnaire and an open-ended question survey was conducted to gauge the participants' attitude s regarding the project. The findings indicated that the participants showed more interest in using and practicing English because of the interaction and the feedback they obtained from their classmates (Aljumah, 2012).

\section{THE ROLE OF THE TEACHER}

The classroom environment cannot be separated from its cultural surroundings. In $t$ he Arab world, the teacher is considered to be a permanent element who demands respect (Grami, 2010). The arrangement of the classroom by which learners sit in rows to pay attention to the teacher ensures that the only figure in the classroom who is under the spotlight is the teacher (Grami, 2010). However, the Saudi government spends billions on developing education and improving teacher skills (Elyas \& Picard, 2010). One of the objectives of King Abdullah's project is to develop education in Saudi Arabia in such a way as to enhance cooperative learning, encourage students' ability to think and engage in problem -solving, thus limiting the teachers' role to that of monitoring and distributing roles between learners (Elyas \& Picard, 2010). Unfortunately, teachers or instructors still have dominant role $\mathrm{s}$ in the classroom s, and learners are only receivers (Whitefield \& Pollard, 1998 as cited in Grami 2012). Some researchers trace the roots of the popularity of the teacher-centered approach to Kuttab- the traditional form of school where the students sat in a circle around a teacher in the mosque and studied religion, reading, and the basics of mathematics (Elyas \& Picard, 2010). In Kuttab, the teacher has the absolute power to teach and punish learners according to his way of thinking, and no-one has the right to question his judgment. In the middle of the last century, the place of Kuttab diminished in favor of public school s, but the similarities between the two systems in terms of the teacher 's role are still obvious (Elyas \& Picard, 2010).

Khuwaileh and Shoumali (2000) conducted a study to compare students' writing $\mathrm{s}$ in their L1, Arabic, and the target language, English. T he results showed that the participants have significant similarities in terms of weaknesses regarding cohesion, coherence, lack of paragraph unity, subject-verb disagreement, and irregular past tenses. This indicated that the challenges of teaching and learning to write skill is not limited to the ESL teachers, but is shared by Arabic teachers as well (Khuwaileh \& Shoumali, 2000). In fact, Arab learners $d$ id not acquire sufficient knowledge of classical Arabic writing, and what they already kn e w about writing in their L1 was based on the regional varieties of the Arabic language (Gherwash, 2015). In other words, the other regional varieties or dialects of Arabic language, where people use 
the vernacular form of the language in speaking and classical Arabic in writing, is one of the main reasons for Arab learners' weakness es in their L1 because they do not have a professional teacher to teach standard Arabic, which is the official language for writing in the first place. As a result, Arab learners use classical Arabic only in specific contexts, e.g. school, which affects their master y of L1 writing. (Hammoud, 2005 as cited in Gherwash, 2015). In this regard, Alnofal (2003) ascertained this fact by conducting a study involving Saudi L2 learners to see if there were significant differences in the training strategies of L1 and L2. The population of the study was 161 male and 42 female undergraduate ESL students studying at American universities. The results revealed that Saudi English L2 learners had more training in writing strategies in English than in Arabic. More specifically, Saudi L2 learners had more training in pre- and post -writing strategies in English than in Arabic, whereas the whole writing process is the same (Alnofal, 2003). It must be noted that this study involves English teachers in the United States who are not as trained as those in Saudi Arabia. This means that L1 writing teachers are not as trained as English language teachers in Saudi Arabia and that the former provide their students with inadequate instructions regarding writing skills. More recent studies confirm these results, and indicate that Saudi L2 learners reported applying few of their writing planning strategies such as drafting and brainstorming in the pre-writing stage, and use the "while writing" strategies more (Alhaisoni, 2012; Alkubaidi, 2014).

\section{TEACHER'S FEEDBACK}

Teacher's feedback on students' writing is considered to be a fundamental aspect of teaching L2 writing (Ferris, 1997; Ferris, Pezone, Tade, \& Tinti, 1997). Two types of feedback are used to improve L2 learners' writing: direct and indirect feedback. Direct feedback is described as feedback that specifically indicates any errors, and provides the correct response, whereas indirect feedback only indicates that a mistake has been made. Both types of feedback improve the students' writing, not only in revision, but also in terms of new pieces of writing (Beuningen, Jong, \& Kuiken, 2012).

As a response to Truscott's (1996) controversial study, in which he rejects the benefits of teacher feedback on students' writing, Grami (2005) investigated the effect of teacher s' written feedback on Saudi E FL university-level perceptions. The study concluded that Saudi EFL student writers prefer to receive feedback from their teachers on their writing, and they believe they will benefit a lot from such feedback (Grami, 2005). Another study shows that Saudi students not only prefer teachers' feedback, but also accept and subsequently believe they will improve from peer feedback on their writing (Grami, 2010). Regarding the amount and type of feedback that is usually given to Saudi learners in E FL classrooms, recent studies show that it focuses on mechanical feedback, e.g. spelling, capitalization, and punctuation (Alshahrani \& Storch, 2014). The mechanical feedback is preferred in crowded classroom situations where the teacher has many papers to review and correct. However, students benefit more from grammar feedback, which is an area they tend to have more difficulties (Hamouda, 2011). In addition to this, students prefer to have direct feedback and explicit comment $\mathrm{s}$ on their errors, while teachers tend to give indirect feedback, (Alkhatib, 2015). Another problem regarding feedback in Saudi EFL classes at the college level is that instructors do not have the luxury of sufficient time to correct all their learners' writing errors due to the large number of students in their classes. Therefore, instructors tend to select typical errors and leave the rest with suggestions for students to correct themselves (Hamouda, 2011).

In conclusion, research shows that both instructors and learners realize the crucial role-played by teacher's feedback in terms of improving L1 learners' writing. However, applying the technique involving teachers' feedback appropriately is still not 
used as extensively as it should be in Saudi classrooms because of the large number of students involved and because teachers and instructors are not trained and encouraged to provide feedback in the classroom. One technique that can be used to ease this difficulty is peer feedback, where students correct their classmate's papers to save time, and allow instructors to focus on the critical mistakes. The obstacle of using peer feedback more widely in the classroom might be due to fact that this technique mainly relates to the collaborative learning method, and classroom $s$ in the Saudi context are still controlled by the authority of the teacher, and because the dominant approaches in EFL classes are the audio-lingual and translation approaches.

\section{MOTIVATION}

In general, motivation has proved to enhance second language learning (Berlin, 2007; Cheung, 2018; Gardner, 1985a; Gardner \& Macintyre, 1991; Guilloteaux \& Dőrnyei, 2008; Waninge, Dörnyei, \& Bot, 2014; Williams \& Williams, 2011) and particularly second language writing (Bacha, 2002). Motivation to write in second and foreign language is influenced by socio-cultural, contextual factors, and prevalent instructional practices in language teaching. In language education, these factors shape up 'the goals of L2 learners' desire to achieve in or through their L2 writing' (Kormos, 2012, p. 398). Sternberg (2017) echoed the same and suggested that motivation is contextsensitive and goal-specific which is directly related to the socio-cultural fabric of the society and the pedagogical practices prevalent in the educational settings. Motivation is essential, but it shouldn't be left to learners to inculcate this in their behavioral patterns, rather the instructors need to adopt effective strategies to make learners independent and autonomous in their learning process (Cheung, 2018; Liu, Wang, \& Ryan, 2016).

However, there are different types of internal and external motivation that can influence the process of learning L2 writing. Internal motivation is divided into integrative and instrumental motivation. Integrative motivation indicates that the learner's interest in learning another language is driven by his /her sincere interest in that language and its culture. On the other hand, instrumental motivation comes from a specific goal associated with learning a task, such as having to interact with English speakers or achieving a job opportunity (Gardner \& Macintyre, 1991). Research has proven that integrative motivation is more beneficial to L2 learners than instrumental motivation (Gardner, 1985b). The setting of the English-learning context in Saudi Arabia indicates that instrumental motivation is the main motivation for learning English (Schumann, 1986). Recent studies have confirmed that Saudi L2 learners are instrumentally motivated (Al-Otaibi, 2004; Alrabai, 2007, 2014b; Al-Seghayer, 2005). Unfortunately, most of the studies that have investigated the relationship between motivation and English language learner s in Saudi Arabia did not focus on college L2 learners, but included public school learners, which give $s$ us a narrow picture with regard to writing skill motivation, since English writing in public school are not extensive.

However, two studies that limited their population to undergraduate participants revealed contradictory results. Alkaff (2013) investigated undergraduate students' attitudes with regard to learning English at King Abdulaziz University. The results show that most students have a positive attitude and that they are motivated to improve their English (Alkaff, 2013). On the contrary, Al-Khairy (2013) found that undergraduate L2 students felt de-motivated. A closer look at both studies explains the contradictions; the previous one focused on participants from the college foundation year, while latter one included sophomore participants. In other words, the participants who have more experience in learning English are less motivated than those with less experience. The negative attitudes of English teachers reported by learners (Al-Khairy, 2013) proves 
that L2 learners are initially motivated when it comes to learning English. However, the practices of English instructors, as well as the negative attitude toward the learners, create a negative atmosphere and de -motivate L2 learners. He observed that there were other factors behind the low motivation level of Saudi learners such as poorly designed study materials, ineffective teaching methods, inadequate use of teaching aids, peer pressure, and of course, inappropriate teaching strategies for grammar and vocabulary. The interrelatedness of other affective factors like attitudes, motivation, anxiety, self-esteem, and autonomy has also been established (Alrabai \& Moskovsky, 2016), so it is quite obvious that all these factors need to be addressed holistically in order to develop a comprehensive framework of pedagogical practice. Another study focusing on undergraduate Saudi learners in Al-Taif university majoring in English report similar results to those of Al-Khairy (2013), in that the majority of L2 learners lack intrinsic motivation (C. Javid, Farooq, \& Gulzar, 2012).

Various studies have observed that that teachers are the strongest determinant of learners' motivation (Al-Johani, 2009; Alrashidi \& Phan, 2015; Khan, 2011), but lack professional efficiency, as they tend to be unduly critical of their mistakes or fail to provide them with real-life examples for their easy understanding and learning of the ideas. In addition, they fail to provide constructive and regular feedback on their development, which consequently results in limiting their progress as well (AlSaraj, 2014). Most of the previous studies have explored the importance of motivation in language learning, but the teachers' aptitude and their understanding of the best strategies in practice are also required to be studied in detail. The educational policies and its relatedness with motivation is also an area which needs to be assessed well to have effective implications on the educational process. It seems that the instructors' roles and their strategies in practice to improve learners' motivation are yet to be fully explored. The instructors need to have an understanding of socio-cultural factors that needs to be taken into account while adopting pedagogical practices for mixed groups of varying motivational levels. Thus, these are the areas that need serious attention of the researchers and practitioners involved in EFL teaching in Saudi Arabia.

\section{ENGLISH WRITING WITH ENGLISH MAJOR LEARNERS}

As mentioned previously, most of the studies that investigated Saudi L2 learner's problems in writing have focused on or included public school students (age range from fourteen to eighteen years). Reasons might be that the English departments in universities do not have the same flexibility as public schools have regarding conducting studies. Also, the population of English departments is usually lesser than that found in public schools, which encourage researchers to focus on public school students for logistical reasons. However, the English departments in Saudi universities are the main source of English teachers as well as English L2 learners. Therefore, focusing on what is happening inside the classroom of these departments will give us a more in-depth view with regard to what happens in other educational institutions such as public schools, community colleges, and preparatory year programs. Three studies have focused on the writing dilemma faced by participants majoring in English in Saudi universities. The first one was conducted in Taif University, which explored the reasons for Saudi English-major undergraduate writing problems, and offered a solution (Al-Khairy, 2013). The participants in the study consisted of 75 English major language students at different levels (sophomores, juniors, and seniors). The instrument used in the research was a 32-items structured Likert-scale questionnaire. In addition, senior faculty members were interviewed. Unsurprisingly, the results were not optimistic, and revealed that the Saudi learners majoring in English were able to produce sentence-level, or a maximum, paragraph-level discourse. The findings revealed that learners showed no interest in learning to write different genres of 
essays (Al-Khairy, 2013).

The present researcher's experience in teaching writing courses for Saudi Englishmajor undergraduates is in the line of Al-khariy's (2013) observation who encountered the same attitudinal issues and weaknesses in teaching writing. This study clarifies that those Saudi L2 learners who are majoring in English, and who should be more proficient writers when compared with their counter parts in other departments, are facing serious problems in writing and are performing below expectations in terms of achievement of the course objectives. The present researcher suggests that in order to overcome this problem, a variety of courses should be introduced to improve Saudi L2 learners' skills in English in general and writing in particular. This suggestion underscores a critical problem in the methodology of teaching English in English departments in Saudi universities. These departments accept students who are very weak in English language, and do not provide them enough courses to improve their use of language so as to enable them to study further advanced courses in linguistics and literature. This means that instructors of the advanced courses are forced to lower the passing requirements for their courses, which then results in the graduation of weak students majoring in English language. This observation is confirmed by a recent study which found a gap between Saudi English language learners' expectations and the instructors' perceptions of the students' needs when it comes to learning writing skills (Almuhailib, 2016).

In another study conducted at Qassim University, the researcher investigated professors' and learners' perceptions with regard to writing difficulties (Almuhailib, 2016). Eighty-six male undergraduate English major learners were enrolled in the program. Two surveys were distributed; one for the professors and the other for the learners. Similar to Al-Khairy's findings (2013), the students revealed micro as well as macro level problems with regard to writing. The results showed that learners have problems in dealing with definite and indefinite articles, using appropriate vocabulary, subject-verb agreement, and spelling. On the macro-level, learners revealed particular concerns about formal skills and writing processes (planning, writing, revision). The study found that using an appropriate academic style is one of the most difficult skills to master (Almuhailib, 2016). These results, along with those of Al-Khairy (2013), show that English language skills and particularly writing skills, are not sufficiently enhanced even after doing specific courses in English language skills, and eventually the learners do not meet the minimum requirement when it comes to master such skills that enable them to study various fields of study like linguistics, literature, and translation. Hussein and Mohammad (2011) found that cultural awareness and familiarity of the topic were important factors to limit negative L1 transfer to L2 writing. It is such a strong feature that the students with familiarity of the topic couldn't resist this negative transfer. In learning to write situation in Saudi Arabia, the learners face difficulties, not only at the structural level like subject-verb-agreement, tense, verb forms, but also at the level of organization, cohesion, and coherence (Khuwaileh \& Shoumali, 2000). As far as Saudi learners are concerned, most of the studies have focused on the product of writing than the process of writing development. There is a need to switch the research focus more on the process; the way instructions are moderated by effective strategies, to achieve the desired outcomes.

Alshammari (2018b) used a different instrument and investigated the teaching of writing skills thoroughly in three English departments in three different universities in Saudi Arabia. The study investigated Saudi L2 learners' experiences in learning English writing in Saudi universities and in American universities. The study limited itself to two conditions regarding the type of participants: those who studied English writing in an English department in a Saudi university followed by their further studying English writing in the Academic English Language Center (henceforth, AELC) of Kansas University in the USA. This condition reduces the participants to three indi- 
viduals. However, the results revealed that though the participants were from three different regions in Saudi Arabia, their K-12 writing learning journey was identical. In school, they neither had systemic writing teaching, nor specific classes for teaching writing styles. The participants revealed that they we re not aware of different types of Arabic writing. However, two of the participants admitted that they enjoyed writing in Arabic, had attempted prose writing, and had published their Arabic writing online. Both participants exclude any influence on the part of formal education on their writing style skill, and attributed their writing skill to self-learning (Alshammari, 2018b).

Regarding their experience of learning English writing in Saudi Arabia, all three participants agreed on major flaws related to studying in an English department at a Saudi university. First, the writing skill courses didn't have a clear and a convincing plan leading to the development of good writing skill. Second, in general, there was insufficient practice of writing in the writing courses, and the instructors focused on theoretical aspects when they gave instructions on writing. Third, the instructors who taught the writing courses were neither specialized in writing nor ha d much experience in teaching writing. Finally, the participants were not benefited sufficiently by the different courses they had in writing. For example, they did not know the types of writing until they studied in the AELC. The students lacked motivation as the feedback provided by the instructors were not comprehensive and encouraging on their writing papers. Regarding their studying in the AELC and comparing it with their experience of studying writing in Saudi universities, all the participants revealed that they had a positive experience in the former, and their writing skill had improved with some variations. Two participants expected the course to be more helpful, but all the participants admitted that the overall experience in the AELC was better than the Saudi experience, (Alshammari, 2018b). However, the body of literature related to English teaching practice in Saudi Arabia can be summarized as follows in Table 4.

Table 4. Major research work related to writing conducted in Saudi context

\begin{tabular}{|c|c|}
\hline \multicolumn{2}{|c|}{ Dominant strategies in teaching writing in Saudi Arabia } \\
\hline GTM & Al-Seghayer (2014) \\
\hline ALM & Bakry and Alsamadani (2015) Mohammad and Hazarika (2016) \\
\hline \multicolumn{2}{|c|}{ - Major research work conducted so far issues related to EFL- } \\
\hline Education policies & $\begin{array}{l}\text { Almalki (2014); Alnefaie and Gritter (2016); Al-Seghayer (2014); } \\
\text { Al-Subahi (1991); Ezza (2010); Naheed (2011) }\end{array}$ \\
\hline $\begin{array}{l}\text { Lack of motivation among } \\
\text { learners }\end{array}$ & $\begin{array}{l}\text { Al-Johani (2009); Al-Khairy (2013); Alrabai and Moskovsky (2016); } \\
\text { Alrashidi and Phan (2015); Khan (2011) }\end{array}$ \\
\hline Ineffective feedback mechanism & Alshammari (2017); Shukri (2014) \\
\hline Lack of clarity in course syllabi & Alshammari (2017) \\
\hline $\begin{array}{l}\text { Lack of well-defined course } \\
\text { objectives }\end{array}$ & Alshammari (2017) \\
\hline Lack of learners' autonomy & $\begin{array}{l}\text { Alhammad (2010) Al-Asmari (2013); Alhareth et al. (2014); Alrabai } \\
\text { (2017a, 2017b); Farahani (2014) }\end{array}$ \\
\hline $\begin{array}{l}\text { Low self-esteem and other } \\
\text { affective factors }\end{array}$ & Al-Hattab (2006); Alrabai (2017c); Alrabai and Moskovsky (2016) \\
\hline $\begin{array}{l}\text { Lack of appropriate use of } \\
\text { technology }\end{array}$ & Alkhatnai (2011); Almutairi (2008); Fareh (2010) \\
\hline $\begin{array}{l}\text { Lack of professional instructors, } \\
\text { lack of authentic texts }\end{array}$ & Alshammari (2017); Fareh (2014) \\
\hline
\end{tabular}

Table 4 shows that most of the studies conducted so far are related to the English language teaching practices and the factors responsible for low outcomes in terms of language skills of the learners. It seems as if language pedagogy itself needs to be 
re-structured considering the related factors, in order to have skill-oriented programs. Writing has completely been neglected over these years as the other primary skills like speaking and listening are yet to be addressed and achieved well. In EFL learning, all the major factors such as L1, status of teachers, feedback mechanism, motivation, status of English major learners etc., have shown to have a holistic idea of the status of teaching writing in EFL context.

However, though many significant studies have shown that effective strategies exist in the teaching of writing, they have not yet found their way to the classroom. The need to establish an educational foundation for applying effective strategies is essential to improve the outcomes of the English departments; otherwise all the studies will be a waste of time and effort.

\section{CONCLUSION}

The root cause of weakness in L2 writing in Saudi Arabia was investigated by searching the outcomes of the most closely-related papers and research in order to prove that the bases of this problem is built on different layers. First, writing is a complicated skill, and the process of teaching it must not ignore important factors such as the learners' L1. In addition to this, new theories of teaching writing to L2 have not yet found their way s into classrooms in the English departments in Saudi universities. Moreover, writing skills are still considered as a secondary course in the English department and is taught by non-certified and untrained instructors; most of the instructors hired have a background in literature, applied linguistics or linguistics, but not in specialized professional courses like Teaching of English to speakers of other language/English as second language/English as foreign language (TESOL/TEFL). Thus, the instructors' methods with regard to teaching writing in Saudi EFL classrooms hinder the process of learning writing rather than supporting it and create a negative impact on the learners' skills.

In an attempt to westernize the educational system, various reforms have been made over the last five years to enhance the outcomes of higher education in Saudi Arabia. Research do suggest that prevalent instructional practices like GTM and ALM are found to be less productive, so methods which are familiar to composition studies need to be put in use, so as to switch pedagogical principle from learning to write to writing to learn. The review does suggest that, in the context of Saudi Arabia, process approach is needed than the product approach in teaching writing, because the cultural setting and the societal norms have serious implications on the pedagogical ('banking model' practices. Hence, the EFL classrooms need to be inclusive ('engagement process'), and the participatory roles of the learners should be encouraged by reducing the teachers' roles as facilitators. Since, a few studies do suggest L1 interference in EFL writing practices, but majority of research do not observe any significant influence as such. However, there are similarities in the pedagogical processes followed in teaching writing in L1 and EFL, which is reflected in learners' poor writing skills.

Limited writing practices and lack of effective feedback are realized as the core component to be addressed by the writing courses; and, this is not limited to EFL instructors only, but the L1 teachers do need to have adequate training in teaching writing. Current feedback practices are more mechanical in nature. Therefore, collaborative learning method should be encouraged so that the learners enjoy autonomy over their learning process. Other than that, integrative motivation is also found to be a crucial factor in this context as the learners lack intrinsic motivation to learn a foreign language; this might be due to the lack of foreign language courses in various universities in Saudi Arabia and lack of job opportunities for foreign language interpreters and translators. These factors eventually have implications on the students majoring in English. 
Through the reading of the studies and papers relating to this topic, it's obvious that skills courses, particularly writing skill courses, are considered to be secondary courses. This attitude may be understandable in English departments in Englishspeaking countries or in the countries where English is the second language, but not in case of Saudi Arabia where English is considered a foreign language and is not spoken outside the classroom. Moreover, the overall motivation behind students joining the English departments in Saudi Arabia universities is instrumentalist (Al-Otaibi, 2004; Alrabai, 2007, 2014b). Therefore, to improve outcomes in general, and particularly in writing, English departments in Saudi universities either need to conduct a proficiency test and set an eligibility criterion of a minimums core to join undergraduate programs or build an extensive English program that focuses on skills, and particularly writing skills.

\section{REFERENCES}

Al-Asmari, A. (2013). Practices and Prospects of Learner Autonomy: Teachers' Perceptions. English Language Teaching, 6, 1-10. https://doi.org/10.5539/elt.v6n3p1

Alhaisoni, E. (2012). The effect of writing proficiency onwriting planning strategy use: A case study of Saudi learners of English. International fournal of Linguistics, 4(3), 78-100.

Alhammad, T. (2010, 02 12). The Education Dilemma in Saudi Arabia. Retrieved from https://www.thecrimson.com/article/2010/2/12/saudi-education-students-school/

Alhareth, A., Dighrir, Y. A., \& ., I. (2014). The assessment process of pupils' learning in Saudi education system: a literature review. American fournal of Educational Research, 2(10), 883-891.

Al-Hattab, A. A. M. (2006). Self-esteem and writing achievement of Saudi EFL students in secondary schools (Unpublished doctoral dissertation). Taibah University, Saudi Arabia.

Al-Johani, H. M. (2009). Finding a way forward: the impact of teachers' strategies, beliefs and knowledge on teaching English as a foreign language in Saudi Arabia (Doctoral dissertation, University of Strathclyde, Glasgow, Scotland, UK). Retrieved from http://oleg.lib.strath.ac.uk/R/?func=dbin-jump-full\&object_id=11539

Aljumah, F. (2012). Saudi learner perceptions and attitudes towards the use of blogs in teaching English writing Course for EFL Majors at Qassim University. English Language Teaching, 5(1), 100-116. https://doi.org/10.5539/elt.v5n1p100

Alkaff, A. (2013). Students' attitudes and perceptions towards learning English. Arab World English fournal, 4(2), 239-250. Retrieved from https://pdfs.semanticscholar.org/26a2/e742be3c8d348e6d4ddee63ad9d7a12af0f1.pdf

Al-Khairy, M. H. (2013). English as a foreign language learning de-motivational factors as perceived by Saudi undergraduates. European Scientific fournal, 9(32), 1857-7881.

Alkhatib, N. I. M. (2015). Written corrective feedback at a Saudi University: English language teachers' beliefs, students' preferences, and teachers' practices (Doctoral dissertation, University of Essex). Retrieved from

https://pdfs.semanticscholar.org/665a/469d13408a617f024522902eeecabe211e80.pdf? ga $=2.159787325 .1046011234 .1586264733-1092603067.1572904032$

Alkhatnai, M. (2011). Learning styles of EFL Saudi college-level students in online and traditional educational environments (Doctoral dissertation, Indiana University of Pennsylvania). Retrieved from ncys.ksu.edu.sa/sites/ncys.ksu.edu.sa/files/Language18.pdf

Alkubaidi, M. A. (2014). The Relationship between Saudi English Major University Students' Writing Performance and Their Learning Style and Strategy Use. English Language Teaching, 7, 83-95. https://doi.org/10.5539/elt.v7n4p83

Almalki, M. M. (2014). Teacher perception of a New English as a Foreign Language (EFL) curriculum in Saudi Arabia (Master's thesis, State University of New York, Fredonia, NY). Retrieved from http://hdl.handle.net/1951/65435 
Almuhailib, B. (2016). Professors' and students' perceptions towards English writing challenges at Qassim University of Saudi Arabia (Master's thesis, State University of New York, Fredonia, NY). Retrieved from http://hdl.handle.net/1951/69340

Almutairi, N. H. (2008). The Influence of Educational and Sociocultural Factors on the Learning Styles and Strategies of Female Students in Saudi Arabia (Doctoral dissertation, Leicester University, Leicester, UK). Retrieved from https://ra.le.ac.uk/bitstream/2381/10217/1/2007almutairinhsphd.pdf

Alnefaie, S. K., \& Gritter, K. (2016). Teachers' role in the development of EFL curriculum in Saudi Arabia: The marginalised status. Cogent Education, 3(1).

Alnofal, A. I. (2003). Arabic First Language Writing and English Second Language Writing Processes: a Comparative Study (Unpublished doctoral dissertation). University of Kansas.

Al-Otaibi, G. (2004). Language learning strategy use among Saudi EFL students and its relationship to language proficiency level, gender and motivation (Doctoral dissertation, Indiana University of Pennsylvania, United States - Pennsylvania). Retrieved from https://search.proquest.com/docview/305099041?pq-origsite=gscholar

Alrabai, F. (2007). The role of intrinsic motivation in learning English as a foreign language by Saudi EFL learners (Unpublished doctoral dissertation). University of Newcastle, Australia.

Alrabai, F. (2014a). A model of foreign language anxiety in the Saudi EFL context. English Language Teaching, 7(7), 82-101. http://dx.doi.org/10.5539/elt.v7n7p82

Alrabai, F. (2014b). Motivational practices in English as a foreign language classes in Saudi Arabia: Teachers beliefs and learners perceptions Fakieh Alrabai. Arab World English Journal, 5(1), 224-246.

Alrabai, F. (2017a). Exploring the Unknown: The Autonomy of Saudi EFL Learners. English Language Teaching, 222-233. https://doi.org/10.5539/elt.v10n5p222

Alrabai, F. (2017b). From teacher dependency to learner independence: a study of Saudi learners' readiness for autonomous learning of English as a foreign language, Learning and Teaching in Higher Education: Gulf Perspectives. Gulf Perspectives, 14(1), 1-28. http://doi.org/10.18538/lthe.v14.n1.262

Alrabai, F. (2017c). Self-esteem of Saudi Learners and Its Relationship to Their Achievement in English as a Foreign Language. English Linguistics Research, 6(4), 1-12. https://doi.org/10.5430/elr.v6n4p1

Alrabai, F., \& Moskovsky, C. (2016). The Relationship between Learners' Affective Variables and Second Language Achievement. Arab World English fournal, 7(2), 77-103. http://dx.doi.org/10.2139/ssrn.2814796

Alrashidi, O., \& Phan, H. (2015). Education context and English teaching and learning in the Kingdom of Saudi Arabia: an overview. English Language Teaching, 8(5), 33-44. http://dx.doi.org/10.5539/elt.v8n5p33

Al-Rubaye, M. H. K. (2015). Meta-discourse in the academic writing of EFL and ESL Arabic-speaking Iraqi graduate students (Master's thesis, Missouri State University, MSU Graduate Theses. 17). Retrieved from https://bearworks.missouristate.edu/theses/17

Al-Saraj, T. M. (2014). Foreign language anxiety in female Arabs learning English: Case studies. Innovation in Language Learning and Teaching, 8(3), 257-278. https://doi.org/10.1080/17501229.2013.837911

Al-Seghayer, K. (2005). Teaching English in Saudi Arabia: Slowly but steadily Changing. In G. Braine (Ed.), Teaching English to the World: History, Curriculum, and Practice (pp. 125-134).

Al-Seghayer, K. (2014). The four most common constraints affecting English teaching in Saudi Arabia. International fournal of English Linguistics, 4(5), 17-26. http://dx.doi.org/10.5539/ijel.v4n5p17

Alshahrani, A., \& Storch, N. (2014). Investigating teachers' written corrective feedback practices in a SaudiEFL context: How do they align with their beliefs, institutional 
guidelines, and students' preferences? Australian Review of Applied Linguistics, 37(2), 101-122. https://doi.org/10.1075/aral.37.2.02als

Alshammari, S. R. (2016). Improving Saudi English learners' second-language acquisition in argumentative writing through self-regulated strategy development (Doctoral dissertation, University of Kansas, Kansas, USA). Retrieved from https://kuscholarworks.ku.edu/bitstream/handle/1808/21995/ Alshammari_ku_0099D_14579_DATA_1.pdf? sequence $=1$ \&is Allowed $=\mathrm{y}$

Alshammari, S. R. (2017). Data Driven Learning and teaching of prepositions in ESL: A study of Arab learners. International fournal of Educational Research and Innovation (IfERI), 12, 153-168. Retrieved from https://www.upo.es/revistas/index.php/IJERI/article/view/3809

Alshammari, S. R. (2018a). The effectiveness of STOP and DARE in planning and drafting argumentative writing: A case of Saudi College Level Students The effectiveness of STOP and DARE in planning and drafting. Arab World English fournal (AWEf), 9(1), 350-364. http://dx.doi.org/10.2139/ssrn.3151123

Alshammari, S. R. (2018b). Experiential study in learning English writing: An inquiry into Saudi learners' concerns. International fournal of English Linguistics, 8(4), 181-191. https://doi.org/10.5539/ijel.v8n4p181

Al-Subahi, A. (1991). Teaching English in the Gulf(Saudi Arabia), Dar Al Funoon Printing Pressa. Jeddah.

Al-Zarah, L. N. (2008). An investigative study of the female initial teacher preparation program in Saudi Arabia in an Islamic context: Perception of the key participants (Doctoral dissertation, Durham University). Retrieved from http://etheses.dur.ac.uk/1893/

Applebee, A. N., \& Langer, J. A. (2009). What is happening to the teaching of writing? English fournal, 98(5), 18-28. Retrieved from https://www.jstor.org/stable/40503291

Bacha, N. N. (2002). Developing learners' academic writing skills in higher education: A study for educational reform. Language and Education, 16(3), 161-177. https://doi.org/10.1080/09500780208666826

Badger, R., \& White, G. (2000). A process genre approach to teaching writing. ELT fournal, 54(2), 153-160. https://doi.org/10.1093/elt/54.2.153

Bailey, K. M. (n.d.). ELT advantage: Content-based instruction (a distance learning course). Boston, MA: Heinle \& Heinle.

Bakry, M. S., \& Alsamadani, H. A. (2015). Improving the Persuasive Essay Writing of Students of Arabic as a Foreign Language (AFL): Effects of Self-Regulated Strategy Development. Procedia - Social and Behavioral Sciences, 182, 89-97.

https://doi.org/10.1016/j.sbspro.2015.04.742

Barnawi, O. Z., \& Al-Hawsawi, S. (2017). English education policy in Saudi Arabia: English Language Education Policy in the Kingdom of Saudi Arabia: Current trends, issues and challenges. English Language Education Policy in the Middle East and North Africa, 13, 199-222. https://doi.org/10.1007/978-3-319-46778-8_12

Berlin, L. M. (2007). Contextualizing College ESL Classroom Praxis. In and others (Ed.), (Vol. 29). Mahwah, NJ: Lawrence Erlbaum Associates.

Beuningen, C. G. V., Jong, N. H. D., \& Kuiken, F. (2012). Evidence on the effectiveness of comprehensive error correction in second language writing. Language Learning, 62(1), 1-41. https://doi.org/10.1111/j.1467-9922.2011.00674.x

Bosede, S. S., Helen, B., \& Oluwakemi, O. (2015). English language prepositions: An Albatross for English Language learners In Nigeria. International fournal of English and Literature, 6(6), 103-108. https://doi.org/10.5897/IJEL2015.0783

Britton, J., Burgess, T., Martin, N., McLeod, A., \& Rosen, H. (1975). The Development of Writing Abilities (11-18). London: Macmillan Education.

Brookes, A., \& Grundy, P. (1990). Writing for Study Purposes: A Teacher's Guide to Developing Individual Writing Skills. Cambridge: Cambridge University Press.

Camp, W. G. (2001). Formulating and Evaluating Theoretical Frameworks for Career and 
Technical Education Research. Journal of Vocational Education Research, 26(1), 4-25. Retrieved from https://scholar.lib.vt.edu/ejournals/JVER/v26n1/camp.html

Cheung, Y. L. (2018). The effects of writing instructors' motivational strategies on student motivation. Australian fournal of Teacher Education, 43(3), 55-73. Retrieved from https://files.eric.ed.gov/fulltext/EJ1174216.pdf

Dewey, J. (1938). Experience and Education. New York: Macmillan Company.

Education First-English Proficiency Index (EF-EPI) . (2018). Report. Retrieved from https://www.ef.com/__ / /media/centralefcom/epi/downloads/full-reports/v8/ ef-epi-2018-english.pdf

Education First-English Proficiency Index (EF-EPI). (2019). Report. Retrieved from https://www.ef.com/__ / /media/centralefcom/epi/downloads/full-reports/v9/ ef-epi-2019-english.pdf

Elyas, T. (2008). The attitude and the impact of the American English as a global language within the Saudi education system. Novitas-ROYAL. Research on Youth and Language, 2(1), 28-48. Retrieved from http://www.novitasroyal.org/elyas.pdf

Elyas, T., \& Picard, M. (2010). Saudi Arabian educational history: Impacts on English language teaching. Business and Society: Contemporary Middle Eastern Issues, 3(2), 136-145. https://doi.org/10.1108/17537981011047961

Ezza, E. S. (2010). Arab EFL Learners' Writing Dilemma at Tertiary Level. English Language Teaching, 3(4), 33-39. https://doi.org/10.5539/elt.v3n4p33

Farahani, M. (2014). From spoon feeding to self-feeding: are Iranian EFL learners ready to take charge of their own learning? Electronic fournal of Foreign Language Teaching, 11(1), 98-115. Retrieved from https://e-flt.nus.edu.sg/v11n12014/farahani.pdf

Fareh, S. (2010). Challenges of teaching English in the Arab world: why can't EFL programs deliver as expected? Procedia-Social and Behavioral Sciences, 2(2), 3600-3604. https://doi.org/10.1016/j.sbspro.2010.03.559

Fareh, S. (2014). Macrolinguistic Errors in Arab EFL Learners' Essays. Procedia - Social and Behavioral Sciences, 141, 923-933. https://doi.org/10.1016/j.sbspro.2014.05.161

Ferris, D. R. (1997). The Influence of Teacher Commentary on Student Revision. TESOL Quarterly, 31(2), 315-315. https://doi.org/10.2307/3588049

Ferris, D. R., Pezone, S., Tade, C. R., \& Tinti, S. (1997). Teacher Commentary on Student Writing: Descriptions \& Implications. Journal of Second Language Writing, 6(2), 155-182. https://doi.org/10.1016/S1060-3743(97)90032-1

Flower, L. (1994). The construction of negotiated meaning: A social cognitive theory of writing. Carbondale, IL: Southern Illinois University Press.

Flower, L., \& Hayes, J. R. (1981). A cognitive process theory of writing. College Composition and Communication, 32(4), 365-387. https://doi.org/10.2307/356600

Freire, P. (1970). Pedagogy of the oppressed. London: Bloomsbury Publishing PLC.

Gardner, R. C. (1985a). Hodder Arnold.

Gardner, R. C. (1985b). Social Psychology and Second Language Learning: The Role of Attitudes and Motivation. London: Edward Arnold.

Gardner, R. C., \& Macintyre, P. D. (1991). An instrumental motivation in language study: Who says it isn't effective? . Studies in Second Language Acquisition, 13(1), 57-72. https://doi.org/10.1017/S0272263100009724

Gherwash, G. (2015). From text to context: literacy practices of native speakers of Arabic in Arabic and English (Doctoral dissertation, Purdue University, Open Access Dissertations. 653). Retrieved from https://docs.lib.purdue.edu/open_access_dissertations/653

Grami, G. M. A. (2005). The effect of teachers? Written feedback on ESL students? Perception: a study in a Saudi ESL university-level context. Annual Review of Education, Communication and Language Sciences. Annual Review of Education, Communication and Language Sciences, 2. Retrieved from https://www.kau.edu.sa/files/0005407/researches/57365_27606.pdf 
Grami, G. M. A. (2010). The Effects of Integrating Peer Feedback into University-Level ESL Writing Curriculum: A Comparative Study in a Saudi Context (Master's thesis, Newcastle University). Retrieved from https://www.kau.edu.sa/files/0005407/researches/57369_27610.pdf

Grami, G. M. A. (2012). Online Collaborative Writing for ESL Learners Using Blogs and Feedback Checklists. English Language Teaching, 5(10), 43-48. https://doi.org/10.5539/elt.v5n10p43

Guilloteaux, M. J., \& Dőrnyei, Z. (2008). Motivating language learners: A classroom-oriented investigation of the effects of motivational strategies on student motivation. TESOL Quarterly, 42(1), 55-77.

Haddad, M. T. (2018). The impact of L1 transfer on the interaction of EFL students with English prepositions. International Forum of Teaching and Studies, 14(2), 20-26. Retrieved from https://pdfs.semanticscholar.org/66e3/b5f1930f2f6604824450ac8fcf7380c4bf62.pdf

Halliday, M. A. K., \& Martin, J. R. (1993). Writing Science: Literacy and Discursive Power. London / Washington, D.C.: The Falmer Press.

Hamouda, A. (2011). A study of students and teachers' preferences and attitudes towards correction of classroom written errors in Saudi EFL context. English Language Teaching, 4(3), 128-141. https://doi.org/10.5539/elt.v4n3p128

Homstad, T., \& Thorson, H. (1994). Writing Theory and Practice in the Second Language Classroom: A Selected Annotated Bibliography (Vol. 8). Retrieved from http://writing.umn.edu/isw/assets/pdf/publications/Homstad_Thorson94.pdf

Hussein, A., \& Mohammad, M. (2011). Negative L1 impact on L2 writing. International Journal of Humanities and Social Science, 1(18), 184-195. Retrieved from http://www.ijhssnet.com/view.php?u=http://www.ijhssnet.com/journals/ Vol_1_No_18_Special_Issue/22.pdf

Ismail, S. (2010). Arabic and English persuasive writing of Arabs from a contrastive rhetoric perspective (Doctoral dissertation, Indiana University of Pennsylvania). Retrieved from https://knowledge.library.iup.edu/etd/632

Javid, C., Farooq, M., \& Gulzar, M. (2012). Saudi English-major undergraduates and English teachers' perceptions regarding effective ELT in the KSA: A comparative study. European fournal of Scientific Research, 85(1), 55-70.

Javid, C. Z., \& Umer, M. (2014). Proceeding of the Global Summit on Education GSE 2014 . In and others (Ed.), Global Summit on Education GSE 2014, March, 4-5, Kuala Lumpur, Malaysia (pp. 4-5). Retrieved from http://ir.uv.es/t97FAfA

Kaplan, R. (1966). Cultural thought patterns in inter-cultural education. Language Learning. A Journal of Research in Language Studies, 16(1-2), 1-20. https://doi.org/10.1111/j.1467-1770.1966.tb00804.x

Kennedy, M. L. (1998). Theorizing Composition: A Critical Sourcebook of Theory and Scholarship in Contemporary Composition Studies. Westport, USA: Greenwood press.

Khan, I. (2011). Learning difficulties in English: Diagnosis and pedagogy in Saudi Arabia. Educational Research, 2(7), 1248-1257. Retrieved from https://ssrn.com/abstract $=2857304$

Kharma, N., \& Hajjahj, A. (1997). Errors in English among Arabic speakers: Analysis and remedy. Lebanon: York Press.

Khuwaileh, A. A., \& Shoumali, A. A. (2000). Writing errors: A study of the writing ability of arab learners of academic English and Arabic at university. Language, Culture and Curriculum, 13(2), 174-183. https://doi.org/10.1080/07908310008666597

Knoch, U., Rouhshad, A., Oon, S. P., \& Storch, N. (2015). What happens to ESL students' writing after three years of study at an English medium university. Fournal of Second Language Writing, 28, 39-52. https://doi.org/10.1016/j.jslw.2015.02.005

Knoch, U., Rouhshad, A., \& Storch, N. (2014). Does the writing of undergraduate ESL students develop after one year of study in an English-medium university? Assessing 
Writing, 21, 1-17. https://doi.org/10.1016/j.asw.2014.01.001

Kormos, J. (2012). The role of individual differences in L2 writing. Fournal of Second Language Writing, 21(4), 390-403. https://doi.org/10.1016/j.jslw.2012.09.003

Lado, R. (1957). Linguistics across Cultures: Applied Linguistics and Language Teachers. Ann Arbor: University of Michigan Press.

Liu, W. C., Wang, J. C. K., \& Ryan, R. M. (2016). Building Autonomous Learners: Perspectives from Research and Practice using Self-Determination Theory. Singapore: Springer. Retrieved from https://doi.org/10.1007/978-981-287-630-0

Mahboob, A., \& Elyas, T. (2014). English in the Kingdom of Saudi Arabia. World Englishes, 33(1), 128-142. https://doi.org/10.1111/weng.12073

Mcmullen, M. G. (2009). Using language learning strategies to improve the writing skills of Saudi EFL students: Will it really work? . System, 37(3), 418-433.

https://doi.org/10.1016/j.system.2009.05.001

Moffett, J. (1968). Teaching the Universe of Discourse. Boston: Houghton Mifflin.

Mohammad, T., \& Hazarika, Z. (2016). Difficulties of learning EFL in KSA: Writing skills in context. International fournal of English Linguistics, 6(3), 105-117.

https://doi.org/10.5539/ijel.v6n3p105

Mu, C. (2005, May 30-Jun 1). A Taxonomy of ESL Writing Strategies. Redesigning Pedagogy: Research, Policy, Practice, Singapore (pp. 1-10). Retrieved from https://eprints.qut.edu.au/secure/64/1/congjun-mu_paper.doc

Naheed, U. (2011). Problems of Multi-ability Academic English Writing Classes in Arab Countries. English fournal, 2(2), 230-242. Retrieved from

https://awej.org/images/Allissues/Volume2/Volume2Number2April2011/9.pdf

Ostler, E. S. (1987). English in parallels: A comparison of English and Arabic prose. In U. Connor, R. B. Kaplan, et al. (Eds.), Writing Across Languages: Analysis of L2 text (pp. 169-185). Reading, Massachussets: Addison-Westley.

Programme for International Student Assessment (PISA). (2015). Report. Retrieved from https://www.oecd.org/pisa/pisa-2015-results-in-focus.pdf

Rajab, H. (2013). Developing speaking and writing skills of L1 Arabic EFL learners through teaching of IPA phonetic codes. Theory and Practice in Language Studies, 3(4), 653-659. https://doi.org/10.4304/tpls.3.4.653-659

Schmitt, N. (Ed.). (2010). An introduction to Applied Linguistics (Second Edition). London: Hodder \& Stoughton Ltd.

Schumann, J. H. (1986). Research on the acculturation model for second language acquisition. fournal of Multilingual and Multicultural Development, 7(5), 379-392. https://doi.org/10.1080/01434632.1986.9994254

Shukri, N. A. (2014). Second language writing and culture: Issues, challenges from the Saudi learners' perspective. Arab World English fournal, 5(3), 190-207. Retrieved from https://www.awej.org/images/Allissues/Volume5/Volume5number3September/15.pdf

Silva, T. (1990). Second language composition instruction: developments, issues, and directions in ESL. In B. Kroll (Ed.), Second Language Writing (Cambridge Applied Linguistics). Research Insights for the Classroom (pp. 11-23). Cambridge University Press. https://doi.org/10.1017/CBO9781139524551.005

Silva, T. (1993). Toward an Understanding of the Distinct Nature of L2 Writing: The ESL Research and Its Implications. TESOL Quarterly, 24(4), 657-667. https://doi.org/10.2307/3587400

Sternberg, R. J. (2017). Intelligence and competence in theory and practice. In A. J. Elliot, C. S. Dweck, \& D. S. Yeager (Eds.), Handbook of competence and motivation: Theory and application (pp. 9-24). The Guilford Press.

Storch, N., \& Hill, K. (2008). What happens to international students' English after one semester at university? Australian Review of Applied Linguistics, 31(3), 1-17. https://doi.org/10.2104/aral0804

Strickland, O. L. (2001). An instrument's conceptual base: It's link to theory. fournal of 
Nursing Measurement, 9(1), 3-4. https://doi.org/10.1891/1061-3749.9.1.3

Swales, J. M. (1990). Genre Analysis: English in Academic and Research Settings. Cambridge: Cambridge University Press.

Truscott, J. (1996). The Case Against Grammar Correction in L2 Writing Classes. Language Learning. A fournal of Research in Language Studies, 46, 327-369.

https://doi.org/10.1111/j.1467-1770.1996.tb01238.x

Waninge, F., Dörnyei, Z., \& Bot, K. (2014). Motivational Dynamics in Language Learning: Change, Stability, and Context. The Modern Language fournal, 98(3), 704-723.

https://doi.org/10.1111/modl.12118

Williams, K. C., \& Williams, C. C. (2011). Five key ingredients for improving student motivation. Research in Higher Education fournal, 12(1), 1-23. Retrieved from http://aabri.com/manuscripts/11834.pdf

Wiseman, A. W. (2010). The use of evidence for educational policymaking: Global contexts and international trends. Review of Research in Education, 34(1), 1-24.

https://doi.org/10.3102/0091732X09350472

Zaid, M. (1993). Comprehensive analysis of the current system of teaching English as a foreign language in the Saudi Arabian intermediate schools (Unpublished doctoral dissertation). University of Colorado, USA. 